few and because of the small rainfall and the excessive loss by ovapotranspiration. The abstraction of ground water from the chalk has risen steadily during the past five years, and a recent report dealing with the River Lee Basin makos suggestions for re-charging this underground reservoir, the level of which is falling alarmingly (River Lee Basin. Hydrological Survey. Hydrometric Aroa No. 38. London: H.M.S.O., 1962. 9s. $6 d$.). Some importation of water from outside the hydrometric area, it is hinted, will be needed.

\section{Food Preservation Quarterly}

THE canning of water for emergency use is discussed by D. J. Casimir in a recent issue of Food Preservation Quarterly (22, No. 2; June 1962). Of the six different treatments which were compared, it was found that the simplest (involving boiling without additions, hot filling and no subsequent retorting) gave a satisfactory product after storage for three years at $100^{\circ} \mathrm{F}$. Among other articles in this issue are the following: accelerated freeze-drying, by J. D. Mellor; a discussion of the mechanism and control of freezer burn, by G. Kaess and J. F. Weidemann; some chemical aspects of food processing, by C. O. Chichester; the use of bulk bins for fruit storage, by E. G. Hall (and Mellor); and the internal corrosion performance of electro-tinplate cans, by E. G. Davis. The journal is published by the Commonwealth Scientific and Industrial Research Organization, Melbourne, Australia.

\section{The National Central Library, London}

THe forty-sixth annual report of the National Central Library for the year ended March 31, 1962, records some progress in planning the new building in Storo Street and it is hoped that actual building can commence by January 1963 (Pp. 26. London: The National Central Library, 1962). Inter-lending again increasod, issues from or through the Library being 87,011 compared with 90,612 in 13 months of 1960-61. Of these, 16,667 were from or through university libraries, 9,953 special outlier libraries, 2,159 Government departments, 3,380 industrial and research organizations and 36,617 public libraries. Loans to libraries overseas totalled 3,699 lent and 2,550 borrowed, while 633 photo-copies were supplied and 786 obtained from abroad. Outlier libraries now number 352. Of 7,546 volumes added to the stock, 4,080 woro purchased, including 851 British Government publications which are now all being purchased. Stress is laid on the part played by university libraries in meeting the needs of other libraries. The present book fund of the Library is about $£ 9,000$, which has to cover books for adult classes as well as binding, but when adequate funds are fortheoming the Trustees consider the Library could function as an effective national lending library. This would be mainly in the humanities, and would not duplicate the large number of books and periodicals already available for loan from other libraries. Besides additional funds for purchase of books and periodicals, additional housing space will also be required.

\section{Ramsay Memorial Fellowships for Advanced Students of Chemistry}

Appliontions for two Ramsay Memorial fellowships for advanced students of chemistry will be considered in February 1963. One of the fellowships will be limited to candidates oducated in Glasgow, but they can apply to be considered for either fellowship. The value of each fellowship will be $£ 750$ per annum, to which may be added a grant for expenses of research not exceeding $£ 150$ per annum, and will normally be tenable for two years. Further information can be obtained from the Joint Honorary Secretaries, Ramsay Memorial Fellowships Trust, University College, Gower Street, London, W.C.1. Completed application forms must be received not later than December 31.

\section{Stimulated Emission of Radiation}

A sHORT course of four lectures on masers is to be held at Battersea College of Technology during November and December, commencing November 22. The title of the course is to be "Stimulated Emission of Radiation". The lecturers will include Drs. G. D. Sims (University College, London), J, C. Walling (Mullards), O. S. Heavens (Royal Holloway College) and Mr. M. S. Lipsett (Imperial College of Science and Technology); the course is under the direction of Mr. G. R. Parlett. The topies to be included are radio and optical frequency masers, their developments and applications. The first lecture will be in the form of an introduction. Further information and application forms can be obtained from the Secretary (Spectroscopy Courses), Battersea College of Technology, London, S.W.11.

\section{Announcements}

Mr. R. L. Michaelson, controller of administration at Elliot Automation, Ltd., has been elected president of the British Computer Society. Last year, Mr. Michaelson was chairman of the Executive Committee of the Society.

A meeting on "The Viscosity and Visco-Elasticity of Inorganic and Organic Glasses", arranged jointly by the Society of Glass Technology and the British Society of Rheology, will be held in the University of Sheffield during January 8-10. Further information can be obtained from Mr. D. Hawksworth, Society of Glass Technology, Thornton, 20 Hallam Gate Road, Sheffield, 10.

A shont course of lectures on "Problems of Radio. activity at Water and Sewage Works", arranged by the Manchester College of Science and Technology, will be held in the College during January 10-11. The programmo will include lectures on: radioactivity; radiation effects; radiation measurement; radiochemical analysis; radioactive waste disposal by discharge to sewers; problems at waterworks; environmental discharge of radioactive waste; and films will also be shown. The fee for the course will be ₹7. Further information and forms of application can be obtained from the Registrar, Manchester College of Science and Technology, Manchester 1.

A MEering of the Illuminating Engineering Society will be held on December 11 at the Federation of British Industries, 21 Tothill Street, London, S.W.1. The programme will include the following papers: "Colour Perception and Colour Rendoring", by Mr. R. W. Brocklebank and Mr. M. H. Wilson (Goethean Science Foundation); "Colour Rendering Tolerances and the Colour Rendering Properties of Light Sources", by Dr. B. H. Crawford (National Physical Laboratory); "Practical Problems of Specifying and Measuring Colour Rendering Properties", by Mr. G. T. Winch. Further information can be obtained from the Secretary, the Illuminating Engineering Society, 32 Victoria Street, London, S.W.1. 